\title{
Synthesis and Characterization of Cao Catalyst from Snakehead Fishbone Impregnated on Fly Ash for Palm Oil Transesterification
}

\author{
Fadarina Fadarina ${ }^{1,}$ Toni Okta Fiyansah ${ }^{* 1}$, Junaidi Bin Mohamad Nasir ${ }^{2}$, \\ Robert Junaidi ${ }^{1}$, Mustain Zamhari ${ }^{1}$, Cindi Ramayanti ${ }^{1}$, Tri Mawarni ${ }^{1}$ \\ ${ }^{1}$ Department, of Industrial Chemical Technology Study Program, State Polytechnic of Sriwijaya, Palembang, 30139, \\ Indonesia \\ ${ }^{2}$ Politeknik Tun Syed Nasir, Hab Pendidikan Tinggi Pagoh KM 1, Jalan Panchor, 84600 Muar, Johor, Malaysia \\ *Corresponding author. Email: tonioktafiyansah1555@gmail.com
}

\begin{abstract}
Waste is organic and inorganic materials from factories and households that are not used that can cause environmental pollution. Some of the waste that is widely found in the South Sumatra region is snakehead fishbone waste from the food industry, and coal fly ash from the Steam Power Plant. Snakehead fishbone contain 39.836\% calcium. Meanwhile, fly ash is beneficial for catalyst support in transesterification reactions because it has a large surface area and pore size. Based on this description, it is necessary to use waste as a valuable product. One solution is to make a catalyst with $\mathrm{CaO}$ as raw material from snakehead fish bones and fly ash as a support, using calcination and impregnation methods. This research aims to produce a catalyst with a short reaction time and calculate the reaction rate with a large $\%$ yield. This research was conducted using the wet impregnation method with variations in impregnation temperature $(70,80){ }^{\circ} \mathrm{C}$ and variations in the mass of $\mathrm{CaO}$ added when impregnated $(80,90,100)$ grams, stirring speed $700 \mathrm{rpm}$, and weight of fly ash 90 grams, with a long time. Transesterification reaction $(30,60,90,120)$ minutes at $60^{\circ} \mathrm{C}$ using palm oil. The results of this study indicate that the impregnation temperature and the mass of $\mathrm{CaO}$ added to the catalyst impregnation stage affect the \% yield produced, reaction rate, and reaction time. From this research, it is known that the best catalyst has an impregnation temperature of $80^{\circ} \mathrm{C}$, and a mass of $\mathrm{CaO} 100$ grams, with a reaction time of 120 minutes capable of producing methyl ester of $98.55 \%$, with a reaction rate of $4.44 \times 10^{-6}$ mol/gramcat.s. The optimum catalyst has a characterization of $96.03 \% \mathrm{Ca}$ absorption $\%$, a specific surface area of $70.78 \mathrm{~m}^{2} / \mathrm{g}$, and the FTIR test results show that $\mathrm{CaO}$ is present in the $\mathrm{CaO} / \mathrm{fly}$ ash catalyst with an intensity of (77-94) \%, at wavenumber $(507-592) \mathrm{cm}^{-1}$
\end{abstract}

Keywords: CaO Catalyst, Transesterification, Imrpregnated, Fly Ash

\section{INTRODUCTION}

Snakehead fish bone waste is waste from the food industry production process that is spread in the city of Palembang. The high consumption of snakehead fish in Palembang, which is often processed into pempek, kemplang, tekwan, and other preparations, can increase the production of snakehead fish bone waste. Based on research, fish bones have the highest calcium content in the fish body [1]. Based on the results of the analysis conducted by Muryati, Hariani \& Said [2], the calcium content in the $\mathrm{CaO}$ powder of snakehead fish bones was $39.836 \%$.
Fly ash is a waste generated by PLTU which contributes to environmental pollution. In this day and age, fossil energy sources are dwindling, and research is required to find and optimize the best waste from fossil fuels into materials that can be useful for other processes. Recent studies have shown that coal fly ash is helpful for transesterification reactions due to its surface area and large pore size [3].

These problems need to be overcome with solutions to utilize some of the waste invaluable products. One solution is to make a catalyst. Catalysts are one of the essential materials in the synthesis process, both organic and inorganic. They are also absorbing to research and 
modify so that their efficiency and use activities can be increased. The biodiesel production process so far uses $\mathrm{NaOH}$ and $\mathrm{KOH}$. This homogeneous catalyst has weaknesses such as easy saponification reactions occur, and it isn't easy to separate the product from the trigger. The biodiesel conversion results are still not too high, while heterogeneous catalysts have different phases from the reactant phase. Heterogeneous catalysts have advantages over homogeneous catalysts, including being easy to separate from the product, being more resistant to free fatty acids contained in the raw material without undergoing a saponification reaction [4].

Calcium oxide $(\mathrm{CaO})$, the most attractive base catalyst in the alkaline earth metal oxide group because of its high alkaline strength, is one of the heterogeneous catalysts found in snakehead fish bone debris. Many researchers have attempted to boost the reaction rate of $\mathrm{CaO}$ since the transesterification catalyzed by it has a poor reaction rate [5].

Research on the transesterification process with $\mathrm{CaO}$ catalysts has been developing for a long time, including a study conducted by Enggawati and Ediati [3], researching the manufacture of $\mathrm{CaO}$ catalysts from chicken eggs impregnated with coal fly ash in a ratio of $1: 1, \mathrm{pH} 12$, at a temperature of $70^{\circ} \mathrm{C}$. For 4 hours and stirring speed of $700 \mathrm{rpm}$. Transesterification of blended oil with the addition of a catalyst of $12 \%$ by weight oil, reaction temperature of $60^{\circ} \mathrm{C}$ for 3.5 hours with a ratio of the volume of oil and methanol 1:3, and stirring speed of $700 \mathrm{rpm}$ produces a yield of 69\%. Asri et al [6] modified a commercial-grade $\mathrm{CaO}$ catalyst from Merck, impregnated on aluminum oxide $\left(\mathrm{Al}_{2} \mathrm{O}_{3}\right)$ in a ratio of $1: 1$, at $80^{\circ} \mathrm{C}$ for 4 hours with a stirring speed of 700 rpm. Transesterification palm oil with the added catalyst $10 \%$ weight of the oil, the reaction temperature is $65^{\circ} \mathrm{C}$, for 5 hours with a ratio of the volume of oil and methanol 1:3 produces a yield of $97 \%$. Aribowo et al [7] modified $\mathrm{CaO}$ catalyst from $\mathrm{Ca}\left(\mathrm{NO}_{3}\right)_{2}$ impregnated on $\mathrm{ZnO}$ with a ratio of $1: 1, \mathrm{pH} 10$, at a temperature of $65^{\circ} \mathrm{C}$ for 3 hours and a stirring speed of $500 \mathrm{rpm}$. It was used to transesterify soybean oil into biodiesel with the use of a catalyst containing $7 \%$ fat by weight, reaction temperature of $60^{\circ} \mathrm{C}$, for 3 hours, yielding a yield of $75 \%$.

Based on the description above, catalyst performance is influenced by variables in the manufacture of catalysts, including impregnation time, impregnation temperature, catalyst concentration on the surface to be impregnated, and calcination temperature [8]. It is known that the highest conversion was obtained from the research of [6], which resulted in a biodiesel conversion of $97 \%$ using a commercial-grade $\mathrm{CaO}$ catalyst from Merck and impregnated in $\mathrm{Al}_{2} \mathrm{O}_{3}$. This result is quite good, but the reaction time required is still very long, namely 5 hours. Asri et al., [6] used a commercial-grade $\mathrm{CaO}$ catalyst from Merck, where the price of this catalyst is relatively high. Meanwhile, the transesterification reaction rate with this catalyst is still relatively low because it takes a long time to convert the reactants into biodiesel.

Based on this background, the obstacle that occurs to the formation of methyl esters related to the manufacture of catalysts is the long reaction time to produce yields above $80 \%$. Therefore, to overcome these obstacles, in this study, the manufacture of $\mathrm{CaO}$ catalyst from snakehead fish bones by the calcination method and $\mathrm{CaO}$ will be impregnated into coal fly ash by the wet impregnation method with variations in impregnation temperature $(70,80){ }^{\circ} \mathrm{C}$ and variations in the mass of $\mathrm{CaO}$. Added when impregnated (80, 90, 100) grams, stirring speed $700 \mathrm{rpm}$, and weight of coal fly ash 90 grams, with a long transesterification reaction time $(30,60,90,120)$ minutes at a reaction temperature of $60^{\circ} \mathrm{C}$ using palm oil as an ingredient. test to determine the speed of the reaction rate, and the mechanism of the $\mathrm{CaO} /$ coal fly ash catalyst

\section{RESEARCH METHOD}

This experiment used snakehead fishbone was obtained from the 26 city market of Palembang and fly ash from PLTU, PT. Bukit Asam, as raw material for making catalysts, and palm oil as raw material for testing the performance of catalysts. This research is divided into four stages: making catalyst, leaching fly ash, catalyst testing, and characterization.

\subsection{Materials and Instruments}

The material used in this study was snakehead fishbone, fly ash, (nitric acid) $\mathrm{HNO}_{3}$, Methanol 99\%, aqua distillation, Palm oil, Methylene Blue, (Chloric Acid) $\mathrm{HCl}$. And the tools used in this research are • Nabertherm Furnace, Nabertherm Oven, $250 \mathrm{ml}$ Decanter, Heidolp MR3001 Hotplate, Ball mill, Sieve Machine.

\subsection{Research procedure}

\subsubsection{Making $\mathrm{CaO}$ Catalyst from snakehead fishbone}

Wash the snakehead fish bones with water and clean meat and membranes that are still attached. Washing is repeated up to 4-5 times. It was drying the snakehead fish bones in the hot sun for 6 hours and drying the snakehead fish bones in the oven for 8 hours at a temperature of $105^{\circ} \mathrm{C}$. Reduce the size of the cork fishbone until you get a fine powder. Sift the fishbone meal using a 100-200 mesh sieve calcining snakehead fishbone powder at a temperature of $950^{\circ} \mathrm{C}$ for 4 hours in a furnace. The calcined $\mathrm{CaO}$ powder was ground using High Energy of Milling (HEM) for 1 hour with a 
$\mathrm{CaO}$ : ball weight ratio of 1: 5. The refined $\mathrm{CaO}$ was stored in a desiccator or closed container.

\subsubsection{Leaching Fly Ash}

Fly ash was sieved through a 200 mesh sieve. Hot air was added to a beaker containing fly ash, then stirred using a mechanical stirrer for 30 minutes. Next, the mixture was decanted and filtered using a Buchner funnel until the solid separated from the air. Fly ash was dried in an oven for 8 hours at $100{ }^{\circ} \mathrm{C}$. Some of the prepared fly ash was taken and cleaned with $10 \% \mathrm{HCl}$ solution with a ratio of fly ash weight and $\mathrm{HCl}$ volume of 1:25 (gr/ml). Every 1 gram of fly ash should be in 25 $\mathrm{ml}$ of $10 \% \mathrm{HCl}$. Washing was carried out using mechanical stirring at $700 \mathrm{rpm}$ for one hour at $80{ }^{\circ} \mathrm{C}$. Next, the mixture was decanted and filtered to obtain a separate ash precipitate. Then, it is left behind with hot aqua distillation to remove the remaining $\mathrm{HCl}$ that is still there and then filtered through a vacuum filter. After that, the residue obtained was dried in an oven for 8 hours at $105^{\circ} \mathrm{C}$.

\subsubsection{Impregnated $\mathrm{CaO}$ on Fly Ash}

Weighing $\mathrm{CaO}$ with mass variations $(80,90,100)$ grams. Dissolve the weighed $\mathrm{CaO}$ in $700 \mathrm{ml}$ of distilled water. Please put it in a beaker and heat it at $60^{\circ} \mathrm{C}$ for 2 hours. A And vice versa for temperature variations, by dissolving 90 grams of $\mathrm{CaO}$ at a temperature of $(70,80)$ ${ }^{\circ} \mathrm{C}$ \}. Then weigh 90 grams of leached coal fly ash, slowly add it to the mixture, and make sure the $\mathrm{pH}$ is maintained at 12. The mixture was stirred for 4 hours with a stirring speed of $700 \mathrm{rpm}$. After that, the mixture was allowed to stand for 24 hours and decanted. The residue was then dried in an oven for 8 hours, at $110^{\circ} \mathrm{C}$. Then it was calcined at $500{ }^{\circ} \mathrm{C}$ for 4 hours.

\subsubsection{Catalyst Performance Test on} Transesterification Reaction

Prepare palm oil and methanol with a volume ratio of 2:3 and prepare a catalyst with a weight of $10 \% \mathrm{w} / \mathrm{w}$ oil. Put the palm oil in a beaker glass and heat it to a temperature of $60^{\circ} \mathrm{C}$. When the reaction temperature has been reached, add methanol and a catalyst with a transesterification reaction time $(30,60,90,120)$ minutes. For a given amount of time, the mixture was swirled at $700 \mathrm{rpm}$. After that, the mixture was allowed to cool and decanted for 3 hours. After that, the filtrate was placed in a separating funnel and left to sit for 30 minutes. Make a distinction between the top and bottom layers. The methyl ester layer is on top, and glycerol is on the bottom. The methyl ester was then rinsed in distilled water at $60^{\circ} \mathrm{C}$ to remove any leftover glycerol and methanol, bringing the $\mathrm{pH}$ back to 7 . The methyl ester and distilled water were then transferred to a separating funnel and allowed to separate into two layers: a methyl ester top layer and a distilled water bottom layer. As well as contaminants. calculating the amount of methyl ester produced.

\subsection{Catalyst Characterization Procedure}

\subsubsection{Analytical Atomic Absorption Spectrophotometry}

It was carried out using atomic absorption spectrophotometry with a calcium lamp, with the steps of making a standard calcium solution, then diluting the sample in the form of a catalyst. Furthermore, setting the gas supply in acetylene gas and instruments according to the desired conditions. Then calibrate with a standard solution, after that it is continued by measuring the sample, where the burning flame is orangeCatalyst Characterization Procedure.

\subsubsection{Analysis of Catalyst Surface Area by Methylene Blue Adsorption Method}

A UV-Vis Spectrophotometer with a wavelength of $664 \mathrm{~cm}$ was used to measure the filtrate. The equation is used to compute the surface area.

$$
S=\frac{X m N A}{B M}
$$

Annotation:

$\mathrm{S} \quad=$ Specific surface area $\left(\mathrm{m}^{2} / \mathrm{g}\right)$

$\mathrm{Xm} \quad=$ methylene blue adsorbed by the catalyst $(\mathrm{g} / \mathrm{g})$

$\mathrm{N}=$ Avogadro's number $\left(6,02 \times 10^{23} / \mathrm{mol}\right)$

A $=$ Methylene blue surface area $\left(197 \times 10^{-20} \mathrm{~m}^{2} /\right.$ molecule)

$\mathrm{BM}=$ molecular weight of methylene blue $(319,86$ $\mathrm{g} / \mathrm{mol}$ )

\subsubsection{Analytical Fouier-Transform Infrared Spectrometer}

Turn on the Infrared spectrophotometer, heat the instrument for \pm 20 minutes before starting the experiment. Let the tool self-test until the device is ready for use $\left(4000 \mathrm{~cm}^{-1}\right)$ on the wavenumber screen. Put the pen on the moment. Pressing the number 0.5 on the chart expansion to set the width of the graph paper on the tool. Press the number 3 on the scan time to put the scan time. I was pressing the wavenumber button $1 \mathrm{x}$, followed by pressing or setting the wavenumber. I was pushing the chat button $1 \mathrm{x}$, followed by pressing or placing the graph paper. Put the polystyrene film on the tool window on the front. Press scan to start scanning. 


\section{RESULTS AND DISCUSSION}

In this research, $\mathrm{CaO}$ catalyst was made from snakehead fishbone by calcination method. The calcination process was carried out at a temperature of $950^{\circ} \mathrm{C}$ for 4 hours with a furnace. The calcination process begins with a transfer of heat to the surface of the particles and passes through the outermost layer of the powder solid. The heat is absorbed by the snakehead fish bone powder so that the resulting $\mathrm{CO}_{2}$ moves and then spreads into the heating area. Then the resulting $\mathrm{CaO}$ was impregnated on the surface of the coal fly ash by the wet impregnation method. When impregnated, $\mathrm{CaO}$ will diffuse into the support pores.

As a result, the catalyst that has been impregnated must be re-calcined at $500^{\circ} \mathrm{C}$ to remove moisture and volatile materials that can cover the surface of the trigger. The catalytic activity with a catalyst with support has a higher strength than a stimulus that does not have [9]. Catalysts manufactured in diverse ways produce a wide range of activity and selectivity. The activity and selectivity of a catalyst in a process are frequently used to assess its capability. The amount of product produced from the number of reactants utilized in a particular reaction period is usually stated as a percentage of conversion. Selectivity is a measure of a catalyst's ability to speed up a reaction in the creation of a certain product.

The results of the catalyst test in the process of making methyl esters which are influenced by the impregnation temperature of the catalyst and the mass of $\mathrm{CaO}$ contained in the trigger, are as follows:

\subsection{Effect of Impregnation Temperature and Mass of CaO on Catalyst Against Methyl Ester Yield.}

Testing of catalysts in making methyl esters is carried out by adding a trigger of $10 \%$ by weight of oil. The reaction that occurs is a transesterification reaction. The catalyst test results at an impregnation temperature of $70^{\circ} \mathrm{C}$ and $80^{\circ} \mathrm{C}$, with a mass of $\mathrm{CaO}$ and reaction time, can be seen in Figure 1. and 2.

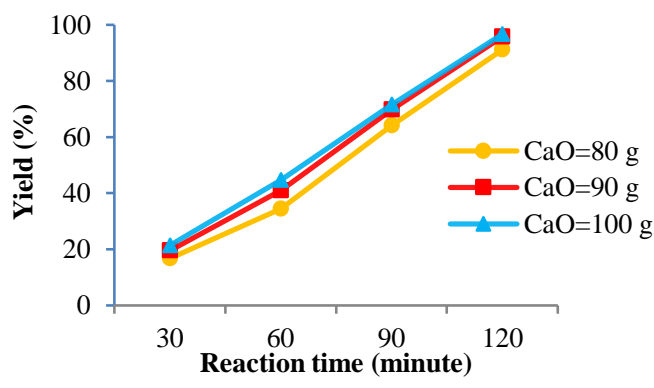

Figure 1. Effect of reaction time and mass of $\mathrm{CaO}$ at an impregnation temperature of $70^{\circ} \mathrm{C}$ on $\%$ yield.

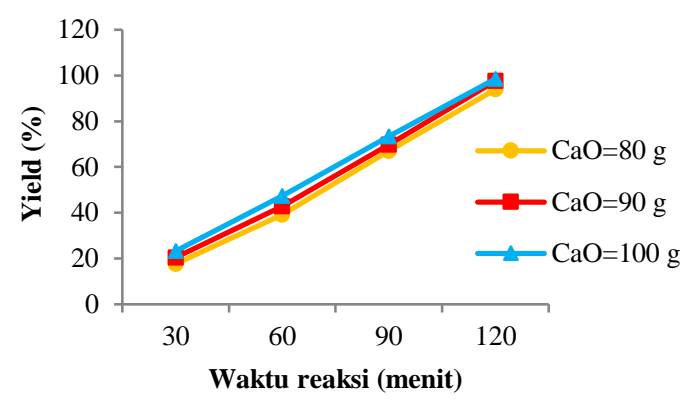

Figure 2. Effect of reaction time and mass of $\mathrm{CaO}$ at an impregnation temperature of $80^{\circ} \mathrm{C}$ on \%yield.

In Figure 1 and 2. Tlonger the reaction time, the greater the yield produced. This is because the length of the reaction time provides a more significant and more extended opportunity for the reactant molecules to collide with each other and react. The significant yield was made at a reaction time of 120 minutes.

The effect of the impregnation temperature of the catalyst can be seen by comparing the yield produced under optimal conditions between the impregnation temperatures of $70^{\circ} \mathrm{C}$ and $80^{\circ} \mathrm{C}$. From Figures 4.2 and 4.3 , it can be seen that the higher the impregnation temperature of the catalyst, the greater the yield produced. The high impregnation temperature causes faster molecular motion, and more $\mathrm{CaO}$ particles collide with coal fly ash. That causes more $\mathrm{CaO}$ to stick to the fly ash pores [10]. So that the optimal condition in the manufacture of $\mathrm{CaO} /$ coal fly ash catalyst is at an impregnation temperature of $80^{\circ} \mathrm{C}$, with the addition of 100 grams of $\mathrm{CaO}$ to 90 grams of coal fly ash, with a reaction time 120 minutes which produces $98.55 \%$ methyl ester.

\subsection{Effect of Impregnation Temperature and Mass of CaO catalyst on Reaction Rate.}

The catalyst made is applied to the methyl ester transesterification process, with the impregnation making temperature and reactant concentration constant. The catalyst test results with variations in the mass of $\mathrm{CaO}$ and reaction time on the reaction rate at impregnation temperatures of $70^{\circ} \mathrm{C}$ and $80^{\circ} \mathrm{C}$ can be seen in Figures 3. and 4.

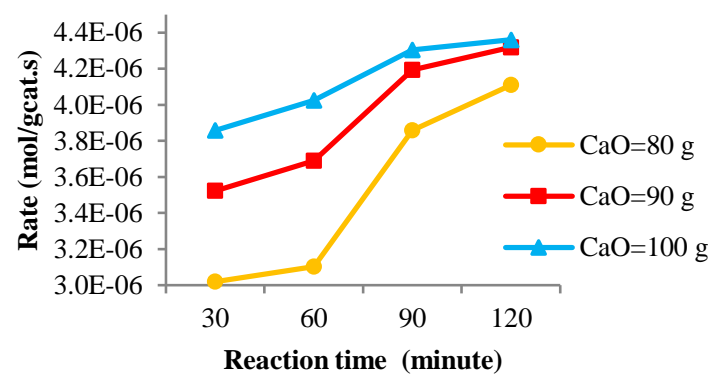

Figure 3. Effect of reaction time and mass of $\mathrm{CaO}$ at an impregnation temperature of $70^{\circ} \mathrm{C}$ on reaction rate 


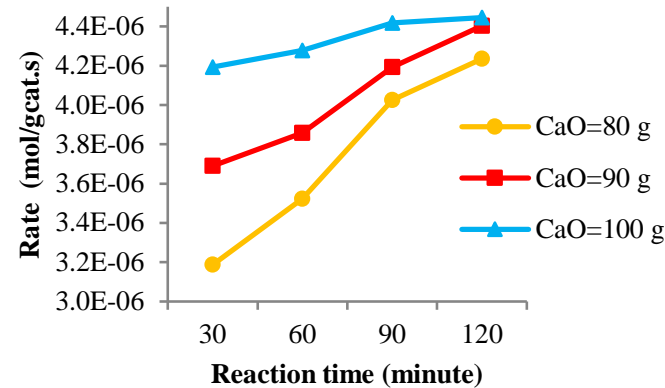

Figure 4. Effect of reaction time and mass of $\mathrm{CaO}$ at an impregnation temperature of $80^{\circ} \mathrm{C}$ on reaction rate

The effect of temperature impregnation can be seen by comparing the optimal conditions at $70^{\circ} \mathrm{C}$ and $80^{\circ} \mathrm{C}$. From Figures 3 and 4, it can be seen that the higher the impregnation temperature, the greater the reaction rate produced. The increase in impregnation temperature causes the movement of $\mathrm{CaO}$ and fly ash particles to accelerate. This movement causes the kinetic energy to increase so that more effective collisions occur. Thus more active sites $(\mathrm{CaO})$ are attached to the support surface. The increase in the amount of support is directly proportional to the reaction rate and the resulting yield. So that the optimal conditions in the manufacture of catalysts to produce effective rates are at an impregnation temperature of $80^{\circ} \mathrm{C}$, the addition of 100 grams of $\mathrm{CaO}$, and a reaction time of 120 minutes with the resulting reaction rate $4.44 \times 10^{-6} \mathrm{~mol} / \mathrm{gram}$ catalyst.

\subsection{Effect of impregnation temperature and mass of $\mathrm{CaO}$ catalyst on rate constant, equilibrium, adsorption, and desorption.}

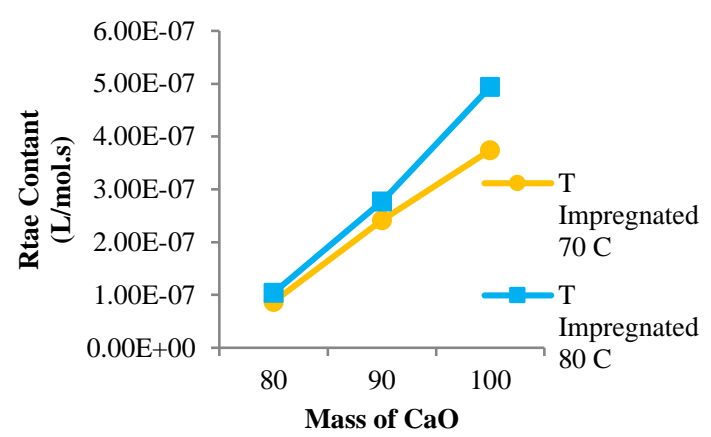

Figure 5. Effect of $\mathrm{CaO}$ mass and impregnation temperature on the rate constant

Figure 5 shows that the higher the mass of $\mathrm{CaO}$ and the impregnation temperature on the catalyst, the greater the rate constant. Every 10-gram increase in abundance of $\mathrm{CaO}$ impregnated on the trigger causes an increase in the rate constant of (1.5-2.7) times. The increase in this constant was caused by the higher the mass of $\mathrm{CaO}$ added, and the higher the impregnation temperature, the reaction rate and yield increased so that the constant rate value was also more excellent [11].

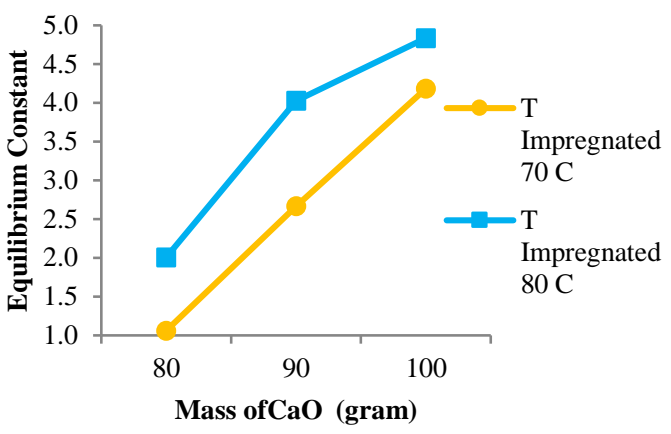

Figure 6. Effect of $\mathrm{CaO}$ mass and Impregnation temperature on the constant surface reaction equilibrium

Figure 6, shows that the greater the mass of $\mathrm{CaO}$ and the impregnation temperature on the catalyst, the greater the value of the equilibrium constant. At an impregnation temperature of $70^{\circ} \mathrm{C}$, the increase in the continuous value was relatively steady. Still, at a temperature of $80^{\circ} \mathrm{C}$, there was a significant increase in the constant value with the addition of $\mathrm{CaO}$ mass above 90 grams. All continuous values in Figure 4.6 are more effective than 1 . Otherwise, it indicates that the reaction tends towards products when equilibrium occurs, with product concentrations greater than reactant concentrations [12].

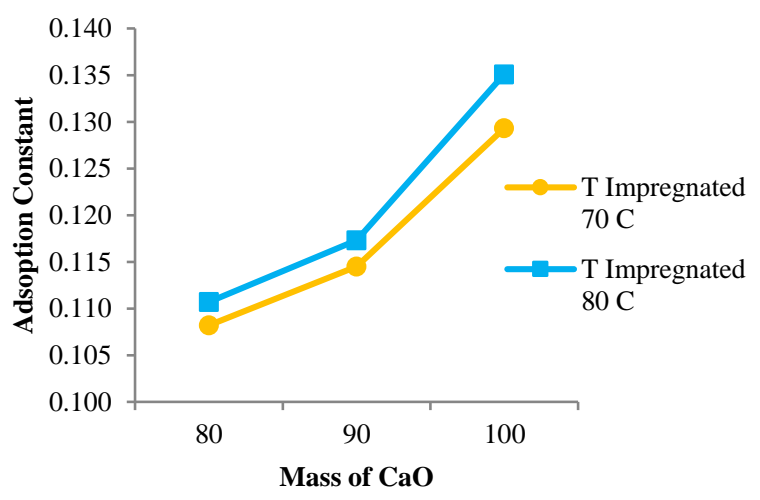

Figure 7. Effect of $\mathrm{CaO}$ mass and Impregnation temperature on the constant Adsorption

Figure 7 shows the effect of the mass of $\mathrm{CaO}$ and the impregnation temperature on the adsorption constant. From the graph, it can be seen that the greater the mass of $\mathrm{CaO}$ and the impregnation temperature, the higher the value of the adsorption constant. An increase in temperature of $10^{\circ} \mathrm{C}$ causes an increase in the continuous value by 1.02 times. And the increased mass of $\mathrm{CaO}$ by 10 grams caused a rise in the value of the adsorption constant of (1.12-1.5) times. The increase in the value of the adsorption constant indicates that the mass of $\mathrm{CaO}$ and the impregnation temperature affect the adsorption process of the reactants on the surface of the catalyst. The increase in the group of $\mathrm{CaO}$ causes more $\mathrm{CaO}$ attached as the active site, and the temperature rise accelerates the collision between $\mathrm{CaO}$ particles and coal fly ash. 


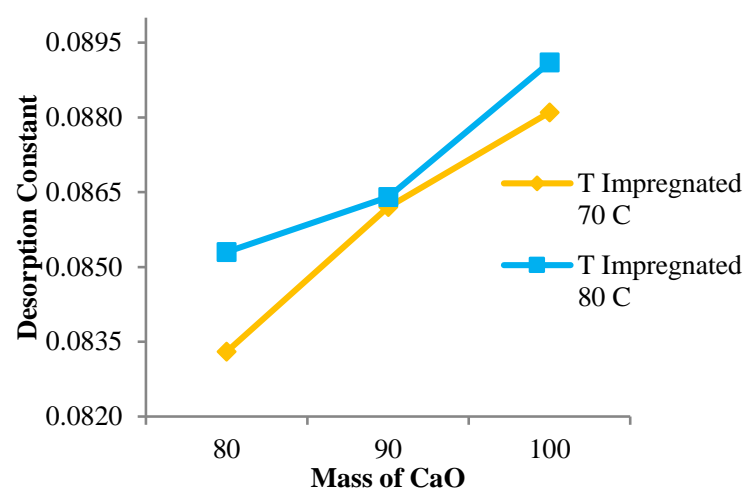

Figure 8. Effect of $\mathrm{CaO}$ mass and Impregnation temperature on the constant desorption

Figure 8, shows the effect of the mass of $\mathrm{CaO}$ and the impregnation temperature on the desorption constant. From the graph, it can be seen that the greater the mass of $\mathrm{CaO}$ and the impregnation temperature, the higher the value of the desorption constant. The increase in the value of the desorption constant indicates that the group of $\mathrm{CaO}$ and the impregnation temperature affect the product desorption process on the catalyst's surface. The increase in the mass of $\mathrm{CaO}$ causes more $\mathrm{CaO}$ attached as the active site, and the temperature rise accelerates the collision between $\mathrm{CaO}$ particles and coal fly ash. If the concentration of active sites is attached to the catalyst, more reactants will be adsorbed so that the desorbed product will also increase [13].

\subsection{Catalyst Characterization}

\subsubsection{Catalyst Characterization with Atomic Absorption Spectrophotometer (AAS)}

The catalyst made by varying the impregnation temperature and the mass of $\mathrm{CaO}$ at the time of impregnation was characterized by AAS (Atomic Absorption Spectrophotometry). To determine how much the highest calcium content is absorbed into the pores of the coal fly ash. The results of the Ca uptake test in fly ash can be seen in Figure 9.

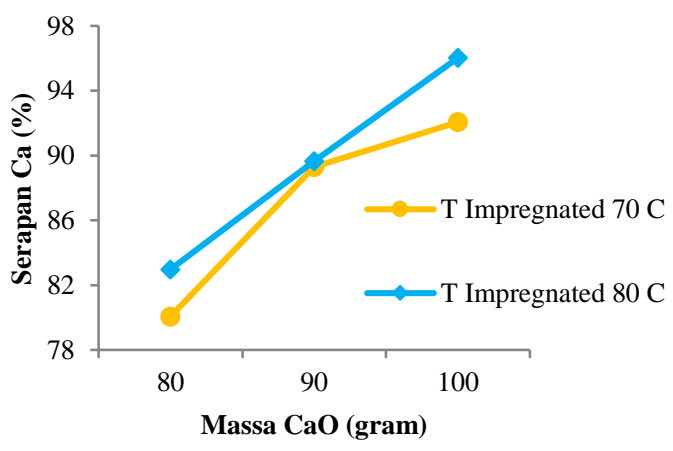

Figure 9. Effect of $\mathrm{CaO}$ mass and impregnation temperature on $\% \mathrm{CaO}$ uptake.
Figure 9 shows an increase in the absorbed $\mathrm{Ca}$ content and the large mass of $\mathrm{CaO}$ impregnated in coal fly ash. At the impregnation temperatures of $70^{\circ} \mathrm{C}$ and $80^{\circ} \mathrm{C}$, it was seen that there was a significant increase between the amount of calcium absorbed and the high mass of $\mathrm{CaO}$ impregnated in coal fly ash. It means the higher group of $\mathrm{CaO}$ and the impregnation temperature, the greater the absorption of $\mathrm{Ca}$ that occurs. $\mathrm{CaO}$ mass causes the impregnated $\mathrm{Ca}$ concentration to be higher, which is one of the factors that affect the calcium content of coal fly ash after the impregnation process. The increase in $\mathrm{CaO}$ mass increased to the active site on the catalyst support. From Figure 4.8, it can be seen the highest calcium absorption found in catalysts with an impregnation temperature of $80^{\circ} \mathrm{C}$ and a mass of $\mathrm{CaO}$ of 100 grams with an absorption $\%$ of $96.03 \%$.

\subsubsection{The specific surface area of the catalyst}

From the yield parameter, reaction rate, constant value, and $\mathrm{Ca}$ absorption value on the catalyst, it is known that the catalyst with the best conditions is a catalyst with an impregnation temperature variation of $80^{\circ} \mathrm{C}$ and a $\mathrm{CaO}$ mass of 100 grams. The methylene blue adsorption method was used to determine the specific surface area of this catalyst. A UV-VIS spectrophotometer with a wavelength of $644 \mathrm{~nm}$ was used to measure the absorbance of methylene blue that had been in contact with the catalyst. The catalyst with an impregnation temperature of $80 \mathrm{oC}$ and a mass of 100 grams of $\mathrm{CaO}$ has a specific surface area of 174.59 $\mathrm{m} 2 / \mathrm{g}$, according to the results of the surface area calculation in appendix B. The reaction takes place on the surface of the trigger in heterogeneous catalysts with solid catalysts. The stimulus must have a wide surface area, typically between 10 and $300 \mathrm{~m} 2 / \mathrm{g}$, but occasionally up to $1000 \mathrm{~m} 2 / \mathrm{g}$ [14].

\subsubsection{FTIR (Fourier Transform Infra-Red)}

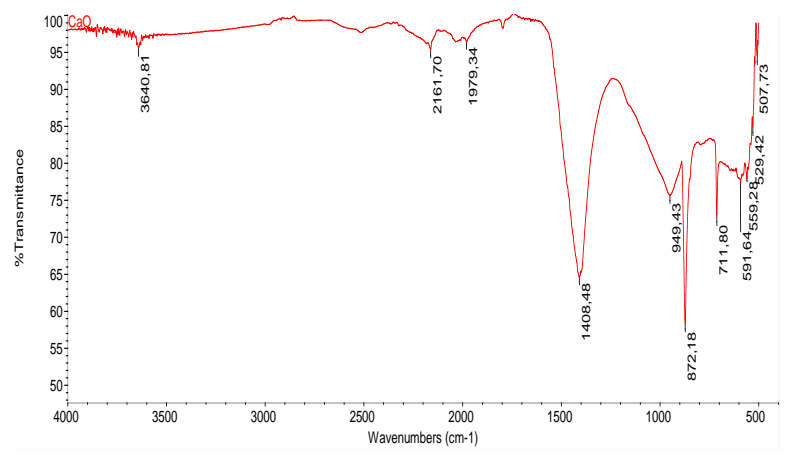

Figure 10. IR spectra of $\mathrm{CaO} /$ fly ash catalyst

The characterization of the catalyst by FTIR was carried out to ensure that the impregnation of the catalyst occurred adequately. Figure 10 shows the results of the FTIR test of a specimen with a $\mathrm{CaO} /$ fly ash catalyst composition. FTIR test results obtained 11 
peaks. At the peak of $507.73 \mathrm{~cm}^{-1}, 529.42 \mathrm{~cm}^{-1}, 559.28$ $\mathrm{cm}^{-1}$, and $591.64 \mathrm{~cm}^{-1}$ are the height of the $\mathrm{Ca}-\mathrm{O}$ bond, which is a calcium oxide compound [15]. There are also Al-O-Si bonds with $711.8 \mathrm{~cm}^{-1}, 872.18 \mathrm{~cm}^{-1}$, and 949.43 $\mathrm{cm}^{-1}$, which are peaks of coal fly ash sourced from the aluminum oxide contained therein. In addition, there is also a peak from the Si-O-Si bond with a height of $1408.48 \mathrm{~cm}^{-1}, 1979.34 \mathrm{~cm}^{-1,} 2161.7 \mathrm{~cm}^{-1}$, which is the peak of coal fly ash sourced from the silica compounds contained in it [16]. Meanwhile, the peak of 3640.81 $\mathrm{cm}^{-1}$ is the peak of the $\mathrm{O}-\mathrm{H}$ bond. The analysis results show the presence of the $\mathrm{OH}$ group is a $\mathrm{Ca}(\mathrm{OH})_{2}$ compound which identifies the possibility of water being adsorbed on the $\mathrm{CaO}$ surface because $\mathrm{CaO}$ is very easy to absorb moisture from the air [17].

\section{CONCLUSION}

The optimal impregnation temperature for the manufacture of the catalyst is $80^{\circ} \mathrm{C}$, with an optimum mass of $\mathrm{CaO} 100$ grams which produces a methyl ester yield of $98.55 \%$ with a reaction time of 120 minutes. The optimum heterogeneous reaction rate on the catalyst surface has a rate of $4.44 \times 10-6 \mathrm{~mol} / \mathrm{gram}$ cat.s, and the values of $\mathrm{k}, \mathrm{KS}, \mathrm{KB}$, and $\mathrm{KC}$ are $4.94 \times 10-7 \mathrm{~L} / \mathrm{mol} . \mathrm{s}$, respectively. $4.8351,0.1351 \mathrm{~L} / \mathrm{mol}, 0.0891 \mathrm{~L} / \mathrm{mol}$. Catalyst characterization showed that the optimum catalyst had $\mathrm{Ca}$ absorption of $96.03 \%$, the specific surface area of the catalyst was $70.78 \mathrm{~m}^{2} / \mathrm{g}$, and the FTIR test results showed that $\mathrm{CaO}$ was present in the $\mathrm{CaO} /$ coal fly ash catalyst with an intensity of (77-94) \%, at wavenumber (507-592) $\mathrm{cm}^{-1}$.

\section{AUTHORS' CONTRIBUTIONS}

All authors provided critical feedback and helped shape the research, analysis and manuscript.

\section{ACKNOWLEDGMENTS}

The research/publishing of this article was funded and facilitated by Politeknik Negeri Sriwijaya. We gratefully thank the Director, Research and Community Service Unit and industrial chemical technology study program of Politeknik Negeri Sriwijaya for their strong support for this research.

\section{REFERENCES}

[1] Putra, M. R. A, Nopianti, R, and Herpandi. (2015). Fortifikasi Tepung Tulang Ikan Gabus (Channa striata) pada Kerupuk sebagai Sumber Kalsium. FishtecH-Jurnal Teknologi Hasil Perikanan, 4(2), 128-139

[2] Muryati, Hariani, P.L, Said, M. (2019). Preparation and Characterization Nanoparticle Calcium Oxide from Snakehead Fish Bone using Ball Milling
Method. Indonesia Journal of Fundamental and Applied Chemistry, 4(3), 111-115.

[3] Enggawati, E. R dan Ediati, R. (2013). Pemanfaatan Kulit Telur Ayam dan Abu Layang Batubara sebagai Katalis Heterogen untuk Reaksi Transesterifikasi Minyak Nyamplung (Calophyllum Inophyllum Linn). Jurnal Sains dan Seni Pomits, 2( 1), 2337-3520.

[4] Zamhari, M., Yuniar., Sari, D, I., dan Saputri, N, S. (2019). Pembuatan Katalis Heterogen Basa dari Serbuk Kayu Akasia. Jurnal Kinetika, 10(1), 3845

[5] Zabeti, M., Daud, W.M.A.W, dan Aroua, M.K. (2009). Activity of Solid Catalysts for Biodiesel Production: A Review. Fuel Processing Technology, 90(1), 770-777.

[6] Asri.N.P., Budikarjono. K., Suprapto., Roesyadi. (2015). Kinetics of Palm Oil Transesterification Using Double Promoted Catalyst $\mathrm{CaO} / \mathrm{KI} / \mathrm{y}-\mathrm{Al}_{2} \mathrm{O}_{3}$. J.Eng. Technol. Sci, 47(4), 353-363.

[7] Aribowo. W., Nugroho. A. IstadiI. (2019). Kinetika Reaksi Transesterifikasi Minyak Kedelai Menjadi Biodiesel Menggunakan Katalis Padat Ramah Lingkungan $\mathrm{K}_{2} / \mathrm{CaO}-\mathrm{ZnO}$. Teknik, 40(3), 136-141.

[8] Yanuar, E., Sarwana, W., Zulkifli., Agustina, A., Sudirman. (2020). Preparasi dan Karakteristik $\mathrm{CaO} / \mathrm{y}-\mathrm{Al}_{2} \mathrm{O}_{3}$ sebagai Katalis. Orbital Chemistry Journal. 1(1), 1-7.

[9] Kristanto.P., Ricky.W., (2003). Penggunaan Minyak Nabati sebagai Bahan Bakar Alternatif pada Motor Diesel Sistim Injeksi Langsung. Jurnal Teknik Mesin, 5(1): 99-103.

[10] Suarsa.I.W., (2017). Teori Tumbukan pada Laju Reaksi Kimia. Denpasar: Universitas Udayana.

[11] Setyawardhani.D.A. (2005). Pengaruh Temperatur Terhadap Reaksi Kesetimbangan Metanolisi Asam Lemak dari Minyak Kacang Tanah. Yogyakarta: UGM.

[12] Budiwati. R. (2019) Kimia Dasar. Bandung : Itenas

[13] Utomo.M.P., Laksono.E.W. (2007). Tinjauan Umum Tentang Deaktivasi Katalis Pada Reaksi Katalisis Heterogen. Prosiding Seminar Nasional Penelitian Pendidikan dan Penerapan MIPA, 9(2), 110-115.

[14] Lestari, D.Y. (2012). Pemilihan Katalis yang Ideal. Prosiding Seminar Nasional Penelitianm Pendidikan dan Penerapan MIPA, 1-6

[15] Gonzalez.M, Hernandez.M, Ascencio.J.A, Pacheco.F, Pacheco.S, and Rodriguez.R. (2003) 
Hydroxyapatite crystals grown on a cellulose matrix using titanium alkoxide as a coupling agent. Journal of Materials Chemistry 13 (12), 2948-2951

[16] Rahim. A.R.H, Azizli. K.A., Man.Z., Rahmiati.T., Nuruddin.M.F. (2014). Effect of Sodium Hydroxide Concentration on the Mechanical Property of Non Ssodium Slilicate Fly Ash Based
Geopolymer. Journal of Applied Sciences, 32(3), 14

[17] Sinha.S., Aman.A.K., Singh.R. k., Kr.N., Shivani.K., (2020). Calcium oxide $(\mathrm{CaO})$ anomaterial (Kukutanda twak Bhasma) from egg shell. Green synthesis, physical properties and antimicrobial behaviour. Materials Today: Proceedings, $\quad 123(3), \quad 1-6$. 